\title{
Uncovering the hillslope scale flow and transport dynamics in an experimental hydrologic system
}

\author{
Minseok Kim¹, Till Volkmann², Bugaj Aaron ${ }^{1}$, Yadi Wang${ }^{1}$, Antônio Meira Neto ${ }^{1}$, \\ Katarena Matos ${ }^{1}$, Ciaran Harman ${ }^{3}$, and Peter Troch ${ }^{1}$ \\ ${ }^{1}$ The University of Arizona \\ ${ }^{2}$ Accenture \\ ${ }^{3}$ Johns Hopkins University
}

November 16, 2020

\section{Uncovering the hillslope scale flow and transport dynamics in an experimental hydrologic system}

Minseok Kim ${ }^{1}$, Till H. M. Volkmann ${ }^{1,2}$, Aaron Bugaj ${ }^{1}$, Yadi Wang ${ }^{3}$, Antônio A. Meira Neto ${ }^{4}$, Katarena Matos $^{4}$, Ciaran J. Harman ${ }^{5,6}$, Peter A. Troch ${ }^{1,4}$

${ }^{1}$ Biosphere 2, University of Arizona, Tucson, AZ, USA, ${ }^{2}$ Applied Intelligence, Accenture, Kronberg im Taunus, Germany, ${ }^{3}$ Department of Environmental Science, University of Arizona, Tucson, AZ, USA, ${ }^{4}$ Department of Hydrology and Atmospheric Sciences, University of Arizona, Tucson, AZ, USA, ${ }^{5}$ Department of Environmental Health and Engineering, Johns Hopkins University, Baltimore, MD, USA, ${ }^{6}$ Department of Earth and Planetary Sciences, Johns Hopkins University, Baltimore, MD, USA

Hillslope scale water flow and transport dynamics have been extensively studied (Burt \& McDonnell, 2015; Hewlett \& Hibbert, 1963), but observing those internal dynamics in high spatial and temporal resolutions remains challenging. In this study, we uncover internal water flow and transport dynamics in an artificial hillslope in the Landscape Evolution Observatory (LEO), Biosphere 2, University of Arizona, Tucson, USA, using the experimental dataset collected in December 2016. Complete information about the hillslope and experiment can be found elsewhere (Pangle et al., 2015; Till H. M. Volkmann et al., 2018); Here, we only summarize some relevant information.

The first part of the animation describes the experimental system and setup (time 00:12 - 04:14 in Animation $\mathrm{S} 1$ ). The LEO hillslope is $330 \mathrm{~m}^{3}$ (30 m long, $11 \mathrm{~m}$ wide, and $1 \mathrm{~m}$ deep) sloping soil lysimeter. The hillslope is primarily made up of loamy-sand textured basaltic tephra, and the most downslope $5.5 \mathrm{~m}^{3}$ is filled with gravel-textured basaltic tephra. A custom irrigation system supplies reverse osmosis filtered water onto the LEO surface. The downslope boundary is exposed to atmospheric pressure, creating the seepage face boundary condition. The sensor networks (including pressure transducers and volumetric water content sensors) and the water isotope sampling locations and intervals ( $7 \mathrm{hrs}$ to $101 \mathrm{hrs)}$ are illustrated in Animation S1 (time 02:09 - 03:01). The isotope composition of subsurface water is obtained from laser-based online measurements of vapor that is extracted via custom gas probes through equilibrium calculation (T. H.M. Volkmann \& Weiler, 2014). The irrigation sequence of this experiment was designed to generate a periodic steady state, which allows the application of the PERidoic Tracer Hierarchy method (Harman \& Kim, 2014) for the observation of the time-variable transit time distributions and the StorAge Selection functions. Deuterium-labeled water was irrigated during the first two irrigation events.

The second part of the animation shows the dynamics of the perched water table and soil water content (time 04:15 - 06:53). The extent of the saturated zone was estimated using the pressure transducer da- 
ta and Delaunay triangulation (Delaunay, 1934). The experimental data show the saturation from below mechanisms - wetting up from the bedrock surface into the soil profile (McDonnell, 1997) — and the saturation from downslope to upslope. The water table profile forms a wedge-like shape, which is a characteristic of hillslope with a high hillslope (Peclet) number (Berne et al., 2005; Brutsaert, 1994). The hillslope Peclet number of the LEO hillslope during the experiment is high (>10) (Kim et al., 2020). Significant time delays in the water table dynamics are observed at some upslope locations (e.g., at $13 \mathrm{~m}$ upslope), which is mostly due to the delayed water supply from the convergent upslope area. The water content data indicates that the convergent upslope water content began to decrease around the timing of the water table peak at $13 \mathrm{~m}$ upslope.

The third part of the animation shows the tracer dynamics (from time 06:43). The animated experimental data reveal two notable water transport dynamics. First, the vertical tracer movement is faster at the upslope. This faster movement at the upslope is, in a sense, counter-intuitive because the upslope region is drier than the downslope. This is due to the lateral flow in the saturated zone and the tension saturated zone, that are thicker at the downslope. While water velocity is higher at the downslope, the direction of velocity is not vertical but rotated towards the downslope in those zones.Second, the animated data illustrate that old water is present only at the downslope. This observation is a characteristic of hillslope with a high hillslope number, in which old water is preferentially discharged (Kim et al., 2020). Indeed, the observed SAS function in this hillslope is concave (Kim et al., 2020), indicating that the hillslope preferentially discharges old water that is stored at the downslope.

\section{Acknowledgment}

This work is supported by the National Science Foundation under grants EAR-1344552 and EAR-1417175. The authors also gratefully acknowledge support from the Philecology Foundation of Fort Worth, Texas. Additional funding support was provided by the Office of the Vice President of Research at the University of Arizona and by the Technology and Research Initiative Fund (TRIF) Water, Environmental, and Energy Solutions (WEES) initiative at the University of Arizona (Shared Equipment Enhancement Funds). The animation is accessible at: http://b2.arizona.edu/LEO_2016/LEO_PERTH_EXP2016.mp4.

\section{References}

Berne, A., Uijlenhoet, R., \& Troch, P. A. (2005). Similarity analysis of subsurface flow response of hillslopes with complex geometry. Water Resources Research , 41 , 1-10. https://doi.org/10.1029/2004WR003629

Brutsaert, W. (1994). The unit response of groundwater outflow from a hillslope. Water Resources Research , 30 (10), 2759-2763. https://doi.org/10.1029/94WR01396

Burt, T. P., \& McDonnell, J. J. (2015). Whither field hydrology? The need for discovery science and outrageous hydrological hypotheses. Water Resources Research , 51 (8), 5919-5928. https://doi.org/10.1002/2014WR016839

Delaunay, B. N. (1934). Sur la sphère vide. Bulletin of Academy of Sciences of the USSR , 6 , 793-800.

Harman, C. J., \& Kim, M. (2014). An efficient tracer test for time-variable transit time distributions in periodic hydrodynamic systems. Geophysical Research Letters , 1567-1575. https://doi.org/10.1002/2013GL058980

Hewlett, J. D., \& Hibbert, A. R. (1963). Moisture and energy conditions within a sloping soil mass during drainage. Journal of Geophysical Research , 68 (4), 1081-1087. https://doi.org/10.1029/JZ068i004p01081

Kim, M., Volkmann, T. H. M., Wang, Y., Harman, C. J., \& Troch, P. A. (2020). Direct observation of hillslope scale StorAge Selection functions in an experimental hydrologic system: Geomorphologic structure and the preferential discharge of old water. Earth and Space Science Open Archive, 44. https://doi.org/10.1002/essoar.10504485.1 
McDonnell, J. J. (1997). Comments on "The changing spatial variability of subsurface flow across a hillside" by Ross Woods and Lindsay Rowe. Journal of Hydrology (NZ) , 36 (1), 97-100.

Pangle, L. A., DeLong, S. B., Abramson, N., Adams, J., Barron-Gafford, G. A., Breshears, D. D., Brooks, P. D., Chorover, J., Dietrich, W. E., Dontsova, K., Durcik, M., Espeleta, J., Ferre, T. P. A., Ferriere, R., Henderson, W., Hunt, E. a., Huxman, T. E., Millar, D., Murphy, B., ... Zeng, X. (2015). The Landscape Evolution Observatory: A large-scale controllable infrastructure to study coupled Earth-surface processes. Geomorphology, August . https://doi.org/10.1016/j.geomorph.2015.01.020

Volkmann, T. H.M., \& Weiler, M. (2014). Continual in situ monitoring of pore water stable isotopes in the subsurface. Hydrology and Earth System Sciences , 18 (5), 1819-1833. https://doi.org/10.5194/hess-181819-2014

Volkmann, Till H. M., Sengupta, A., Pangle, L. A., Dontsova, K., Barron-Gafford, G. A., Harman, C. J., Niu, G.-Y., Meredith, L. K., Abramson, N., Neto, A. A. M., Wang, Y., Adams, J. R., Breshears, D. D., Bugaj, A., Chorover, J., Cueva, A., DeLong, S. B., Durcik, M., Ferre, T. P. A., .. Troch, P. A. (2018). Controlled Experiments of Hillslope Coevolution at the Biosphere 2 Landscape Evolution Observatory: Toward Prediction of Coupled Hydrological, Biogeochemical, and Ecological Change. In J. Liu \& W. Gu (Eds.), Hydrology of Artificial and Controlled Experiments . InTech. https://doi.org/10.5772/intechopen.72325 